\title{
Analyzing Toyota City’s Eco-policy Through Strategic Marketing Tools
}

\author{
Hiroshi Ito ${ }^{1}$ \\ ${ }^{1}$ Graduate School of Management, NUCB Business School, Nagoya, Japan \\ Correspondence: Hiroshi Ito, Graduate School of Management, NUCB Business School, 1-3-1 Nishiki, Naka \\ Ward, Nagoya, Aichi 460-0003, Japan. Tel: 81-52-203-8111. E-mail: hito@nucba.ac.jp
}

Received: December 28, 2018

doi:10.5539/ass.v15n4p23
Accepted: March 3, 2019 Online Published: March 29, 2019

URL: https://doi.org/10.5539/ass.v15n4p23

\begin{abstract}
Toyota City has long been making efforts to promote its eco-policy based on five eco-themes: transportation, the urban center, industry, forests, and the public welfare and livelihood. A previous study that examined changes in citizens' awareness regarding the city's eco-policy between 2012 and 2015 illustrated that while the city has been successful overall to communicate its eco-policy to citizens, it has failed to do so in some eco-themes such as industry or forests. That is, despite some improvement, promoting the city's eco-policy still remains an issue. This paper analyzes Toyota City's eco-policy by using strategic marketing tools to help elaborate on effective eco-policy promotion in the framework of social marketing. Given that the ultimate goal of eco-policy is to promote citizens' pro-environmental behaviors, the concept of social marketing is relevant here, as it includes the promotion of public policies, including eco-policies. Social marketing also may help understand why some cities succeed to promote their eco-policies while others fail to do so and elaborate on an effective policy-making and promotion. In this article, I will first describe a brief overview of Toyota City's eco-policy. I will next employ different kinds of marketing approaches that may be relevant to promoting eco-policy. I will then employ several strategic tools (i.e., marketing mix, strategic purposes, PEST, strategic groups, and SWOT) to help analyze Toyota City's eco-policy. This article ends with some discussions about how to promote the city's eco-policy.
\end{abstract}

Keywords: eco-policy, environmental assessment, strategic marketing tools, Toyota City, Japan

\section{Introduction}

Toyota City has long been facing and addressing environmental issues in large part because of industrial activities by the Toyota Motor Corporation (TMC) and its affiliated companies. In collaboration with these companies and other stakeholders (e.g., civil society and citizens), the city government has elaborated on and implemented action plans to improve the environment (Toyota City, 2009). In 2009, Toyota was designated by the Japanese government as one of the eco-model cities (EMCs). These EMCs pursue low carbon societies to reduce greenhouse gases, while enhancing sustainable socioeconomic development. Since then, Toyota City has accelerated efforts to promote its eco-policy, including the establishment of Ecoful Town (a pavilion showcasing Toyota's eco-policy), provision of free pamphlets and concept books for children, creation of a Facebook account that lists eco-related events, and implementation of environmental education in public schools within the city (Ito \& Kawazoe, 2017).

A previous study regarding Toyota City's eco-policy examined changes in citizens' environmental awareness and found that their environmental awareness related to the city's eco-policy significantly improved overall between 2012 and 2015 (Ito \& Kawazoe, 2016). However, whereas Toyota City has been successful in promoting some eco-themes, such as transportation, the urban center, and the public welfare and livelihood, it has failed to promote other eco-themes, such as forests and industry. The transportation theme is comprised of the following eco-items: the next generation cars (NGCs) such as electric vehicles (EVs) and plug-in hybrid (PHV) and Ha:mo (a car-sharing system using compact EVs for urban transportation). The urban center theme is comprised of: Ecoful Town and the heat island effect. The public welfare and livelihood theme is comprised of: the smart house and the home energy management system (HEMS) that utilizes information technology to control energy consumption. The forests theme refers to kanbatsu (periodic thinning that removes trees from dense stands to make room for other trees). The industry theme refers to development of sustainable plants (factories with systems that create, store, and economize energy). 
Since the 2009 designation of Toyota City as an EMC, the most significant change among these eco-items is the 2012 establishment of Ecoful Town, which was arguably a driving force in communicating the city's eco-policy to citizens, especially the urban center theme. Whereas citizens' recognition about transportation theme items, such as NGCs, and the public welfare and livelihood theme items such as the smart house improved, citizens' recognition about forest- (kanbatsu) and industry- (sustainable plants) related policies did not, implying that Toyota citizens were not aware of these activities during the research period.

The reasons why the themes of forests and industry are not as recognized as the others are detailed elsewhere (Ito \& Kawazoe, 2016) and this article did not discuss them. Instead, it will analyze Toyota City's eco-policy as a whole by using strategic marketing approaches and tools to help elaborate on effective eco-policy promotion. This article is structured as follows: I will first describe different kinds of marketing approaches that could be applied to promoting eco-policy. I will next introduce several marketing approaches that can be relevant to promoting eco-policy and strategic tools. I will then employ (e.g., marketing mix, strategic purposes, PEST, strategic groups, and SWOT) to analyze Toyota City's eco-policy. This article ends with some discussions about how to promote Toyota's eco-policy.

\section{Marketing Concepts Applicable in Promoting Eco-policy}

Given that eco-policy is part of public policy, its promotion may involve public sector marketing as well as green and sustainable marketing, all of which are kinds of social marketing (Butler et al., 2007; Kotler \& Keller, 2011; Rettie et al., 2012). Employing social marketing is appropriate in promoting eco-policy because both social marketing and eco-policy pursue changing citizens' behaviors through informing them of and educating them about eco-policy. In the following sections section, I will elaborate on these different marketing approaches and connect them to Toyota City's eco-policy.

\subsection{Social Marketing}

Social marketing is defined as "the use of marketing principles and techniques to influence a target audience to voluntarily accept, reject, modify, or abandon behavior for the benefit of individuals, groups or society as a whole" (Helmig \& Thaler, 2010, pp. 264-265). Similarly, social marketing seeks to influence social behaviors to benefit the target audience and the general society (Andreasen \& Kotler, 2007). Social marketing interventions are designed to be focused specifically on behavior and applicable to encouraging pro-environmental behaviors (Gregory-Smith et al., 2015).

Social marketing was originally linked with selling of ideas suggested by Kotler and Zaltman in their 1971 article and their conceptualization of social marketing as "the selling of ideas shifted over time to focus on voluntary individual behavior change" (Wood, 2016, p. 108). Today, "social marketing is widely recognized as a credible behavior change discipline with governments across the globe" (Rundle-Thiele, 2015, p. 128). This statement indicates that social marketing, including public sector marketing as well as green, sustainable, and environmental marketing, is applicable to promote Toyota City's eco-policy.

According to Da Silva and Mazzon (2016), social marketing campaigns are consisted of three different levels of actions: 1) diagnosing the social problem; 2) influencing the social change to the target population; and 3) setting the social marketing mix. Although marketing involves (value) exchange between stakeholders (e.g., buyers and sellers) (Smith \& Brower, 2012), the concept of exchange in social marketing is more complex than commercial marketing because it involves intangible products such as well-being by improving the environment, and the benefits are not immediate. The social change occurs when the target audience recognizes the benefits of the change and very decision is made related to audience's perspective. The problem is designed to fulfill the audience's needs and desires. This diagnosis of the social problems (eco-related issues in Toyota City) and citizens' current knowledge and behaviors about the eco-policy is what previous studies have so far done. This study will explore how to promote the eco-policy hereafter in the framework of social marketing approaches.

Although "social marketing has emerged as a popular and straightforward approach to promote environmental behaviors" (Takahashi, 2009, p. 135), we hardly find literature "adopting a public marketing perspective or particularly focusing on green public services targeted to external stakeholder entities" (Boenigk \& Möhlmann, 2016, p. 87). Indeed, public sector marketing receives limited attention (Aspara \& Tikkanen, 2016) as public sector organizations find marketing little relevance to their activities (Scrivens, 1991).

\subsection{Public Sector Marketing}

In recent decades, public services have increasingly been subjected to the application of market principles (Osborne \& Gaebler, 1992). In the public sector, market orientation has been shown to enhance customer satisfaction with public services (Walker et al., 2011). However, there has been criticism of the market 
orientation concept's focus on performance, with claims that the government's marketization of public services has a negative impact on public trust (Taylor-Gooby \& Wallace, 2009), as the market's emphasis on entrepreneurialism and satisfying the individual's self-interest is incompatible with demographic accountability, citizenship, and an emphasis on collective action in public (Denhardt \& Denhardt, 2015). Although social marketing might come to be a significant tool in government behavior-change programs (Madill \& Abele, 2007), in application of social marketing by governmental organizations, social marketing suffers from high complexity, low compatibility with government practices, few opportunities to observe social marketing in action in like organizations for like purposes as well as few opportunities to try it out in one's organization (Madill \& Abele, 2007). It has also been shown that social marketing may not be well understood by senior managers in government organizations (Madill \& Abele, 2007) because marketing is associated with "advertising and selling products or services to a susceptible public, an action which seems unnecessary when demand for services in the public sector often exceeds supply" (Burton, 1999, p. 374).

Likewise, in the public sector, marketing is often considered non-productive and resource consuming (Parker et al., 2007) because the general purpose of marketing (i.e., making profits) (Laing \& McKee, 2001) seems contradictory to the mission of the public sector (i.e., serving the general interest of society dealing with non-rival public goods, including environments) (Butler \& Collins, 1995). Walsh (1991) argues, marketing approaches are unlikely to be either helpful or appropriate in the distribution of basic social goods. Therefore, marketing is often considered business activities and irrelevant to the public sector.

Several scholars argue that policy-makers tend to consider marketing to support corporate interests, industry associations, or lobby groups. This "suspicion by policy makers" may greatly hinder the utilization of marketing research in the public sector (Aspara \& Tikkanen, 2016, p. 4). French and Russell-Bunnett (2015) also state that "government agencies...do not fully understand how social marketing relates to, contributes to and challenges other approaches to social policy delivery" (p. 143). However, the public sector often finds it difficult to communicate policies to citizens and the use of and application of marketing concepts and techniques may be useful to do so (Kaplan \& Haenlein, 2009).

While these is a concern about the public sector being too receptive to "marketization" (Molander et al., 2018, p. 77). Nonetheless, concepts such as contestable markets, increased citizen orientation, and the systematic use of information in public organizations (Walker et al., 2011) that has the potential to enhance public service delivery. Therefore, the potential exists for marketing concepts to make a significant contribution to the effective management of public services in contemporary society (Wright, Moynihan, \& Pandey, 2012).

Public organizations are providers of social goods and services. Public service provision increasingly takes place in the context of markets and quasi-markets, and is more and more organized and coordinated by market forces. As market agents, public organizations are therefore necessarily engaged in marketing (Butler et al., 2007). Indeed, behavioral change is the anticipated long-term effect of many public marketing models (Helmig \& Thaler, 2010; Laing, 2003; McMahon, 2002). In the context of changing environmental behavior, the public sector strives to implement marketing strategies to foster green attitudes of citizens (Boenigk \& Möhlmann, 2016). This kind of marketing, with emphasis on changing environmental behaviors through marketing approaches may be called green marketing and/or sustainable marketing.

\subsection{Green/Sustainable/Environmental Marketing}

Green, sustainable, or environmental marketing is a marketing of products and/or services that are environmentally friendly. Its concept has emerged from social marketing (Kotler \& Keller, 2011; Smith \& Brower, 2012). Green marketing refers to the marketing of products and services that are presumed to be environmentally preferable to others and to stimulate and maintain one's environmental attitudes and behaviors (Jain \& Kaur, 2004). It is also defined as "holistic management for identifying, anticipating and satisfying the requirements of customers and society, in a profitable and sustainable way" (Peattie, 1995, p. 28). It is a broad-based approach that puts equal importance on environmental, social equity and economic/financial concerns when developing strategies. This has resulted in many organizations worldwide increasingly developing internal and external strategies that are green or environmentally sustainable (D’Souza et al., 2018).

According to Polonsky (1994), green marketing is defined as "all activities designed to generate and facilitate any exchange intended to satisfy human needs, with minimal detrimental impact on the natural environment" ( $p$. 2). Peattie (2001) defines green marketing as "marketing activities which attempt to reduce the negative social and environmental impact of existing products and production systems" (p. 129). Green marketing also refers to the analysis of how marketing activities impact on the environment and how the environmental variable can be incorporated into the various decisions of corporate marketing (Chamorro et al., 2009; Wymer \& Polonsky, 
2015).

Similar to green marketing, sustainability marketing is "the planning, coordination, implementation and controlling of all market transactions in such a way that a sustained satisfaction of the needs of current and potential customers toward the achievement of corporate objectives is granted" as well as "contributing toward reducing ecological and social impacts and restoring social and ecological health" (Kirchgeorge \& Winn, 2006, p. 176). Rettie et al. (2012) explain that sustainability marketing includes both commercial marketing of green products and services and social marketing of pro-environmental behaviors.

As described later, sustainability marketing can be used to support and drive processes of social normalization and denormalization: sustainability marketing can encourage consumer adoption of sustainable activities by repositioning them as mainstream and normal, and unsustainable activities as anormal (Rettie et al., 2012). Overall, these marketing approaches are all related to the public sector, and thus, some marketing tools may serve to analyze and promote cities' eco-policies.

\section{Analyses of Toyota City's Eco-policy}

In this section, I analyze Toyota City's eco-policy using marketing strategic tools, such as marketing mix and strategic purposes for internal analyses, and PEST (i.e., political, economic, social, and technological factors) and strategic groups for external analyses, followed by SWOT (i.e., strengths, weaknesses, opportunities, and threats). Both marketing mix and strategic purposes are pivotal for any organization to identify its raison d'etre as well as strengths and weaknesses (e.g., what do they want to achieve, what do they do to do so, what do they do well or do not do well). PEST and strategic groups are important to understand opportunities and threats (e.g., environmental factors and competition). SWOT serves as a synthesis of internal and external factors. Collins, Tapp, and Pressley (2010) state that these strategic and diagnostic tools provide the kind of analytical power for social marketers. Understanding these factors helps Toyota City identify which strengths to be more strengthened to become competitive advantages and which weaknesses should be overcome, in relation to other eco-cities and eco-policies as well as socio-economic and environmental situations.

\subsection{Internal Analyses}

\subsubsection{Marketing Mix}

The marketing mix often refers to 4Ps (i.e., Product, Price, Place, and Promotion). Despite limited empirical evidence on the exact role and contribution of the marketing mix, it is the widely "trusted conceptual platform of practitioners dealing with tactical/operational marketing issues" (Constantinides, 2006, p. 408). Although 4Ps have originally derived from business marketing, they can be applied to social marketing as well. Madill and Abele (2007), for example, note that the use of 4Ps is one of the characteristics of social marketing programs. Peattie and Peattie (2003) describe the social, including the public sector, marketing mix as follows:

Product: Although the desired social behaviors are sometimes seen as the end product of social marketing, social marketing is about offering propositions such as 'exercise is beneficial' or 'drinking and driving ruins lives' (Peattie \& Peattie, 2003, p. 371). In the context of Toyota City's eco-policy, the proposition is to aim at "normalizing eco-life in the future (or to make eco-life normal in the future)" (Toyota City, 2017). Product in social marketing is generally intangible as it is an idea, behavior, action, orientation, prevention, or treatment, and arises from social problem analysis by external environments, but intangible products can be followed by tangible ones e.g, eco-family cards/eco-points (Da Silva \& Mazzon, 2016).

Price: Given the absence of a monetary price in most social marketing contexts, price is usually interpreted as the costs of behavior change (e.g., monetary ones such as purchase of more expensive eco-friendly products as well as non-monetary ones such as physical, time, social, and psychological). The price of promoting Toyota City's eco-policy is also considered the direct monetary cost of change toward pro-environmental behaviors. For instance, the cost for the city government is to provide eco-related information through brochures or events and subsidize citizens to buy eco-products.

Place: In social marketing, place refers to accessibility and the locations involved in the intended behavior change or the campaigns aimed at influencing behaviors. When it comes to accessibility issues in the location of social marketing interventions, 'this is an area where social marketers often seem to be particularly creative in ways that distinguish their campaigns from the conventional social education approach' (Peattie \& Peattie, 2003, p. 374). In the case of Toyota City, Ecoful Town and Ha:mo stations are the main places of intervention, but schools, households, shops and restaurants, and even the streets can also be the places of intervention (Ito \& Kawazoe, 2016; Ito \& Kawazoe, 2017).

Promotion: promotion often is equated to communication both in commercial marketing (van Waterschoot \& van 
den Bulte, 1992) and social marketing (Nagahama, 2014). Promotion bridges commercial and social marketing campaigns: commercial marketing theories and practices are seen as entirely applicable to social marketing contexts (Peattie \& Peattie, 2003). Communication is important to persuade the target audience and explain how the social marketing campaign will support them (Da Silva \& Mazzon, 2016). Thus, promotion requires understanding the target audience as well as their media habits in order to define the content of messages, communication, and media to achieve the individuals' mind in seeking two results: positioning the campaign benefits; and ensuring a sustainable and healthy relationship between social marketers and target audience (Da Silva \& Mazzon, 2016). In the context of Toyota City's eco-policy, the provision of leaflets, concept books, the Facebook account, subsidies for NGCs and the smart house, and Ecoful Town can be considered elements of promotion.

Sargeant (2009) explains that, 6Ps - the 4Ps plus Partnerships and Policies-are appropriate for nonprofit and public sector marketing. In establishing partnerships, many nonprofit and public organizations seek collaborations with other stakeholders, possibly with similar goals. As already mentioned, the Toyota Motor Corporation is a notable collaborator for Toyota City. Toyota City has not collaborated with any other specific city, but, for example, Kyoto City and Yokohama City, which pursue low carbon societies as environmental model cities, could be potential partners. Toyama City and Amagasaki City, other environmental model cities, are also potential partners (as well as candidates for comparative study of eco-policies) in terms of similarities in city population sizes.

Policies often involve legal enforcement (e.g., punishment) to compel citizens toward behavioral change. In Toyota City, instead of punishing citizens without taking actions, it encourages them to buy eco-products such as NGCs and the smart house through subsidies. In partnerships with the Toyota Motor Corporation and its affiliated companies, the Japanese government, and others, the city could expand on the range of eco-products to be subsidized.

\subsubsection{Strategic Purposes}

Strategic purposes (i.e., mission, vision, and objectives/goals) help organizations articulate why they exist and what they should do to justify their existence. Lankard and McLaughlin (2003) argue that it is important to look at "antecedent factors when developing a promotion strategy or campaign. Thus, before an organization can develop its messages, it must look at its overall corporate mission, philosophy and goals" (p. 417). Johnson et al. (2011) state that strategic purposes are influenced by governance structure, social responsibility, and stakeholder expectations. They emphasize the concept of stakeholders and the purpose of the organization to be understood by stakeholders. Similarly, Da Silva and Mazzon (2016) note that the mission of the social marketing plan must meet the interest of individual in the campaign; specify the needs that the campaign focuses on; incorporate the values of sponsor organizations; describe and identify the benefits of the campaign; introduce the real purposes and goals of campaigns in the long term; and define what the organization expects in the long term (i.e., normalizing eco-life or becoming a low carbon society in the context of Toyota City's eco-policy).

An organization's mission aims to provide stakeholders with a clear purpose of the organization. A mission statement is an important strategic tool with an emphasis on effective communication and associated with improved performance for functions (Pandey, Kim, \& Pandey, 2017). The mission of Toyota City's eco-policy is to make it an economically and environmentally friendly city and to build a low carbon society with a comfortable lifestyle for the future by improving citizens' environmental knowledge, attitudes, and behaviors.

An organization's vision is an action plan to achieve the mission concerned with the desired future state of the organization. Toyota City's vision is concentrated on promoting the five eco-themes (i.e., transportation, forests, the urban center, industry, and public welfare and livelihood) through a smart transportation system and NGCs, forests that benefit citizens, eco-friendly industry with sustainable plants, a green urban center, and smart houses with solar panels, and citizens who act pro-environmentally (Toyota City, 2009).

An organization's objectives are statements of specific and often quantified outcomes that help achieve the mission and vision. For instance, Toyota City has been working on reducing carbon emissions by cutting $\mathrm{CO} 2$ by $30 \%$ by the year 2030 . Making $20 \%$ of the urban area green, as part of countermeasures against the heat island effect, is another example of Toyota City's objectives. Since 1990, CO2 has been cut by $8 \%$ and green spaces increased by $14.2 \%$ (Toyota City, 2012). The former objective is unlikely to be achieved at this pace.

\subsection{External Analyses}

\subsubsection{PEST}

In diagnosis of social problems such as environmental ones, as Da Silva and Mazzon (2016) note, the social 
marketing environments are important factors to be taken into account. The PEST framework categorizes the external macro-environmental influences into four main factors: political (the role of local, national, and international governments), economic (macro-economic factors), social (cultural and demographic factors), and technological (innovations) (Johnson et al., 2011; Bovaird, 2003). PEST can be used to review a strategy or position, direction of an organization or a marketing proposition (Halík, 2012). This analysis tool can be applied to Toyota City's eco-policy to help the city identify its position and direction toward promoting eco-policy.

Political: The Japanese government is supportive of eco-policies in general and Toyota City has been designated by the government as an environmental model city. Therefore, the political atmosphere toward eco-policy, including that of Toyota City, has been positive. Also, the international community has increasingly been adopting eco-friendly policies and campaigns (See Table 1 of the SWOT analysis in a later section). This provides a great opportunity for Toyota City to show itself as an international exemplar of an eco-city as well as to learn from other eco-cities inside and outside Japan about promotion of their eco-policies.

Economic: Eco-friendly products, such as NGCs and the smart house, are generally more expensive than ordinary products, and initial investments to install eco-facilities, such as solar panels, are costly. For instance, EVs on average cost 30,000 USD, almost doubled in price compared to similar fuel engine cars. However, the use of these eco-items may allow citizens to spend less energy and thus energy costs and the purchase of eco-products, such as NGCs and the smart house, is subsidized by the Japanese government and Toyota City, and HEMS can also help an efficient use of energy by monitoring energy consumption. For instance, the national government subsidizes up to 400,000 yen (or 3670 USD) and city government subsidizes up to 250,000 yen (or approximately 23,000 USD) to individuals who buy EVs and PHVs, or up to 80,000 yen (or approximately 734 USD) to those who install solar panels and HEMS (Toyota City, 2018b). The issue may be that many citizens do not seem to be entirely convinced to purchase these eco-products.

Social: According to Blery, Katseli, and Tsara (2010), if "[t]he mentality of people changes, they understand the problems and they become more sensitive with the protection of the environment" (p. 63). Whereas citizens are increasingly searching for green and healthy lifestyle choices (Ministry of the Environment, 2012), the city government needs to consider the fact that the population is aging rapidly and focus attention on the well-being of the elderly in the context of eco-policy. For instance, while promoting NGCs remains important, it is urgent for Toyota City to promote public transportation (or to a lesser extent, a car sharing system like Ha:mo) because it has been the main means of transportation for the elderly.

Technological: Some of the eco-technologies relevant to Toyota City's eco-policy, such as NGCs and the smart house with solar panels and HEMS, have already been adopted in Toyota City. However, NGCs, especially EVs (Lebeau et al., 2013) and smart houses (Jahromi, Rajabzadeh, \& Manashty, 2011) are expensive. Also, the lithium battery's life span still remains limited around 10 years (Masih-Tehrani et al., 2013). While adapting to changing technology is a matter of urgency, the city's capacity to do so is quite limited and has to rely on the private sector for advancement.

Macro-environmental factors analyzed by PEST seem positive for Toyota City's eco-policy. Politically, the Japanese government and the international community are supportive of environmental initiatives, including those of environmental model cities. Economically, the purchase of eco-products has also been financially supported through subsidies by the Japanese government as well as the city government of Toyota City. Socially, citizens are more aware of environmental issues (though priority seems to be given to other social issues). The aging of population means that Toyota City can encourage the concentration of living along public transportation routes and create commercial facilities toward the establishment of a compact city for the efficient use of energy and/or resources. Technologically, eco-technologies have been advancing, but some issues (e.g., higher costs of eco-products and NGC's short lithium battery life span) remain unsolved.

\subsubsection{Strategic Groups}

Pegels and Sekar (1989) note that strategic groups are essentially subgroups within an industry. Each subgroup is considerably different from other subgroups, but each subgroup they exhibits considerable homogeneity and similarity. Thomas and Pruett (1995) explain that the concept of strategic groups directs attention to those groups of firms in an industry, which may compete with each other. Marlin, Ketchen, and Lamont (2007), citing Porter (1979), define strategic groups as clusters or sets of firms that pursue similar competitive approaches within an industry. Although environmental model cities are not competitors with each other, they have common objectives and features as well as different strategies that distinguish one from another. Therefore, the concept of strategic groups may help identify the positioning of Toyota City's eco-policy in relation to other environmental model cities. 
Promoting eco-policy mainly involves two strategic aspects: 1) visibility calculated based on the number of many official recognitions awarded such as environmental model cities, environmental future cities, SE4ALL, and Rockefeller RCs as well as OECD, and 2) functionality estimated based on a) progress in eco-initiatives, b) greenhouse gas absorption, c) creation of regional vitality, d) regional originality, and e) promotion and development of eco-initiatives, with each from one to five points (25 points in total) (Cabinet of Japan, 2012). Visibility is important because if the eco-policy is not well recognized by stakeholders, it will fail to attract support and resources. Functionality is also important because unless actions are taken to achieve a mission and vision, its raison d'etre will be in question and it will likely lose support and resources eventually (Figure 1).

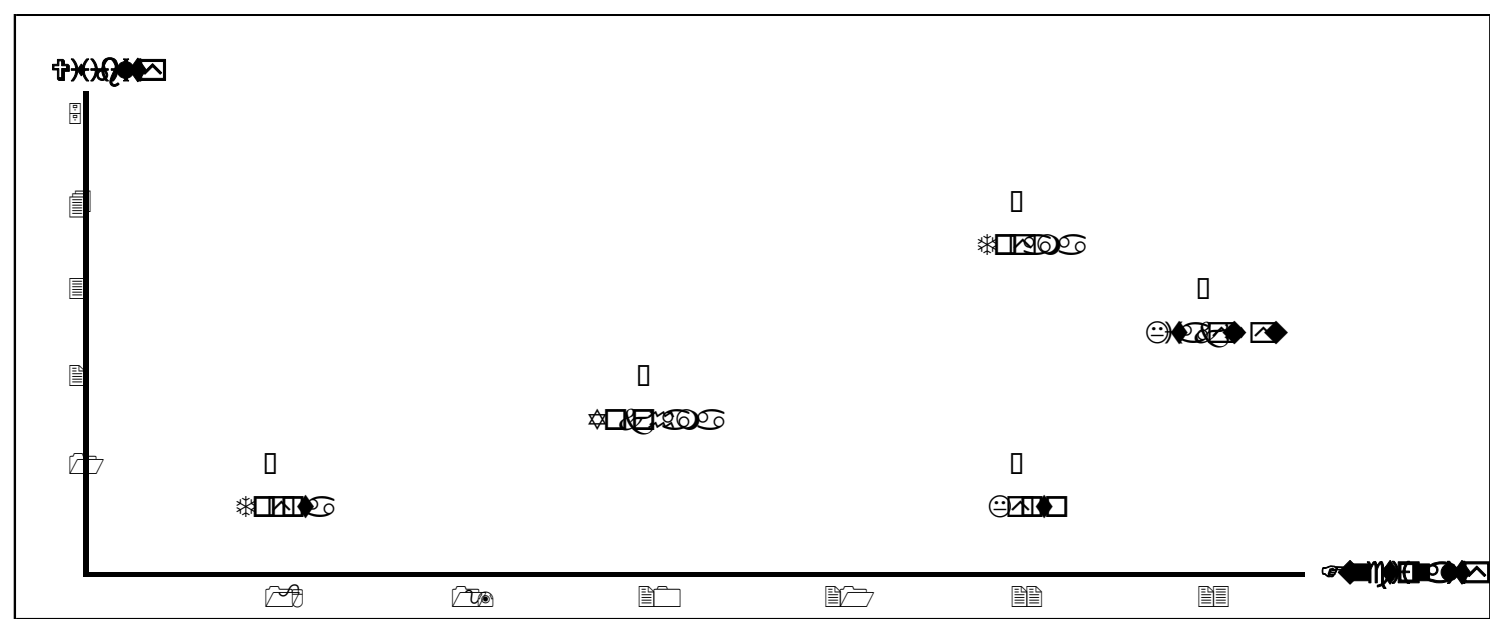

Figure 1. Positioning of major model cities in terms of visibility and functionality based on the assessment of environmental model cities by Cabinet of Japan (2012)

These environmental model cities are selected for the following reasons. For instance, Kyoto City developed pedestrian-centered urban planning, with expanded sidewalks and priority given to public transportation (Kyoto City, 2015). Kyoto City has one point in visibility because it has been designated only as an environmental model city and 22 points in functionality based on the aforesaid five criteria. Yokohama City aims to promote a zero-carbon lifestyle to its citizens, with shared knowledge, greater choices, and active involvement, for example, in increasing the use of renewable energy tenfold by 2025 and provision of subsidies for energy-saving houses (Yokohama City, 2015). The city has two points in visibility because it has also been designated as an eco-future city (EFC) by the Japanese government. Like environmental model cities, EFC is an eco-initiative launched in 2011. This initiative aims at solving the challenges of the environment, aging, economic growth, international diffusion, and local revitalization (Future City Initiative, 2018). The city has 20 points in functionality. Regarding Kitakyusyu City and Toyama City, albeit smaller in the population size than the above-stated cities, their eco-policies have been quite successful in grabbing recognition nationally and internationally. Kitakyusyu City has also been designated as an EFC by the Japanese government and its green growth trends, challenges, and opportunities were spotted, reported, and published by OECD (2013). Kitakyusyu City has introduced renewable energy such as solar- and wind- power generation systems as well as EVs, rooftop gardens, and LED lightning. The city has three points in visibility because, in addition to EMC and EFC, it has been reported by an eco-model city by OECD. The city has 23 points in functionality. The Toyama's eco-policy may be even more noteworthy. Toyama City has been addressing these issues by what is called the compact city strategy. Toyama's compact city policy is to revitalize public transportation, to concentrate city functions in the city center and along the transportation lines, and to promote energy efficiency and alternative energy sources (Toyama City, 2018a). The city has four points in visibility. Aside from becoming an environmental model city in 2008 and EFC in 2011, the city was targeted for an assessment case study for OECD's compact city policies, and designated as a model city of the Sustainable Energy for All Initiative by the United Nations (UNSE4ALL) in 2014 (Toyota City, 2015) and of the 100 Resilient Cities Initiative by the Rockefeller Foundation in 2014 (100 Resilient Cities). The city has 22 points in functionality. Compared to the above-stated environmental model cities, Toyota City's eco-policy may still leave a lot of room for improvement in terms of visibility (one point) and functionality (18 points). 


\subsection{SWOT}

According to Da Silva and Mazzon (2016), the last important step in diagnosis of social problems is "to understand and organize in two category: opportunities and threats from the outside environment... and thereafter, understand the inside environment, which is called strengths and weaknesses" (p. 580). SWOT can be used to summarize and develop the analyses of internal and external factors that can positively or negatively affect Toyota City's eco-policy. SWOT is a commonly used tool to examine the internal strengths and weaknesses of an organization and the external opportunities and threats that an organization should be aware of (Hill \& Westbrook, 1997). SWOT may help identify major strengths and translate them into competitive advantages (Coman \& Ronen, 2009).

Identifying one's SWOT is critical in making strategic choices that encourage the successful achievement of an organization's strategic purposes and plans for the future (Poister, 2003). SWOT is not without criticism. For instance, Kanno (2014) argues that SWOT cannot solve real world problems because they are much more complicated than what SWOT analyzes. However, there is a general agreement that SWOT serves as a comprehensive analysis tool of the micro- and macro environments of organizations, including public entities. SWOT thus serves to analyze and promote Toyota City's eco-city (Table 1).

Table 1. SWOT analysis of Toyota City in promoting eco-policy

\begin{tabular}{lll}
\hline & Positive factors & Negative Factors \\
\hline Internal & Strengths: Toyota City is relatively affluent and & Weaknesses: Toyota City is not a major city in size, with \\
attributes & internationally known mainly due to the Toyota a population of 423,000. The city's eco-policy's \\
& Motor Corporation. These companies financially recognition and impact therefore may be limited, as it is \\
and technologically support Toyota City in the capital city of the Aichi prefecture compared to & \\
& eco-related themes and eco-events, including the major cities' eco-policies, such as those of Kyoto City \\
& 2015 High-Level Symposium on Sustainable Cities and Yokohama City. For instance, major broadcasting \\
& (Toyota City, 2015). The city is also able to companies are located in capital cities of prefecture. \\
& subsidize citizens with the purchase of eco-products Also, Toyota City is a car dominant society because of \\
& such as NGCs and smart houses. Toyota City Hall the Toyota Motor Corporation's presence. The full \\
& also has a specific department responsible for implementation of a car-sharing system like Ha:mo or \\
promoting eco-policy, apart from the department in the development of public transportation like LRT are \\
charge of environment policy.
\end{tabular}

External Opportunities: The environment and sustainability attributes have been hot global issues. Various international conferences on these issues have been held, such as the 1992 UN Conference on Environment and Development in Rio de Janeiro, the 2002 World Summit on Sustainable Development in Johannesburg, and the 2012 UN Conference on Sustainable Development Rio +20 . Conferences of the Parties (COPs), an international convention where all world states discuss environment and sustainability issues, also take place every year. The UN Sustainable Development Goals set to be achieved by 2030, consist of addressing many issues regarding the environment and sustainability (United Nations, 2015).
Threats: Environmental issues do not seem to be a major concern for Japanese citizens, compared to other issues such as health care, social welfare, education, community development, culture, art, and sports. (Pekkanen, 2006). According to Nagasaka (2007), the number of memberships in Japan's environment-related organizations is smaller than other countries, such as the US, UK and Germany. For instance, the US National Wildlife Federation, the UK National Trust, and the Nature Conservation Society of Germany have at least a few million members respectively. In contrast, Japan's largest environment-related organization is the Wild Bird Society of Japan with 50,000 members followed by WWF with 40,000 and the Nature Conservation Society of Japan with 10,000.

*Constructed by the author

To summarize, Toyota City is a relatively known and affluent city with the financial and technological support mainly from the Toyota Motor Corporation. Yet, the city is not large in population size and its eco-policy is difficult to receive international recognition, although, it hosts eco-related events nationally and internationally once in a while. The international community and the Japanese government are supportive of eco-policies in general. Yet, Japanese citizens, including those of Toyota City, are not concerned about the environment and climate change as much as other social issues such as health care or social welfare. 


\section{Discussion}

So far, internal and external factors were introduced to help assess Toyota City's eco-policy. Positive sides are: The Japanese government and the international community are supportive of environmental initiatives, including those of environmental model cities. The purchase of eco-products has also been financially supported through subsidies by the Japanese government and the city government of Toyota City, which also receives financial and technological support from the Toyota Motor Corporation and other stakeholders. The aging of population means that Toyota City can also encourage the concentration of living along public transportation routes and create commercial facilities toward the establishment of a compact city for the efficient use of energy and/or resources.

In this context, with support from the government and the private sector, Toyota City has been making efforts to establish Ecoful Town and Ha:mo and enhace the purchase of NGCs and the smart house to promote eco-policy nationally and internationally. Nonetheless, Toyota City has issues with promoting eco-policy, as many citizens do not recognize the city's eco-policy and have not changed their eco-behaviors at the socially desired level. Therefore, some of the objectives set to achieve a mission and vision is unlikely to be achieved. The issue of promotion may be relevant to partnerships: while Toyota City has been working closely with the Toyota Motor Corporation, it has not collaborated with other eco-cities. It is suggested that Toyota City should collaborate with and learn from other eco-cities, for example Toyama City, as it has been successful in promoting its eco-policy.

Toyama City is selected as both an environmental model city and an environmental future city by the Japanese government. Also the city has been selected as a model city of the District Energy in Cities Initiative (SE4ALL: Sustainable Energy for All) by United Nations and the Resilient Cities Initiative by the Rockefeller Foundation. There is no doubt that Toyama City has been successful in promoting eco-policy nationally and internationally.

Toyama City is similar to Toyota City in population size and arguably more disadvantaged without a presence of global company like the Toyota Motor Corporation, but succeeded in receiving national and international recognition. Despite limited resources available to support eco-city initiatives, Toyama City has competed against other cities and won because it has (created) competitive advantage, competing strength gained over others by offering greater values (Ehmke, 2012). According to Porter (1985), competitive advantage can be generated through the following factors: 1) cost leadership; 2) differentiation; and 3) focus. Cost leadership is an advantage in that an organization offers the same services as its competitors but at a lower cost. Differentiation is an advantage where an organization delivers higher quality services for the same price as its competitors. Focus is a strategy in which an organization concentrates on narrow, exclusive segments and establishes market niches. An organization can possess competitive advantage when it creates and/or adds unique value based on these factors (Campbell et al., 2012; Gaddis Ross, 2014; Goldsmith, 2013). Joldersma and Winter (2002) state that public organizations like the city government should determine its strategy with concentration on differentiation and focus. Nonetheless, social marketing practitioners, including city government personnel, might not be segmenting their target audience adequately and are aiming at influencing as many people as possible (Takahashi, 2009). Toyama City's case suggests one important lesson in marketing strategy: it differentiates itself from other eco-cities by focusing on investing in and/or selling one or a few eco-items (Hsieh \& Chen, 2011; Huselid, 1995; Porter, 1985). While the city's strategy is comprehensive, its focus on public transportation, evolved around LRT, makes the city unique and differentiates its eco-policies from those of other cities. Back in the 2000s, the use of LRT was considered out of date and obsolete in Japan. Nonetheless, the city decided to re-establish the LRT system and used it as a pivotal tool for success. That is innovation. Although innovation is often considered new technological invention, using old things and ideas in new ways is also innovation (Hargadon \& Sutton, 2000). Since innovation is unique and valuable (Kim \& Mauborgne, 1997), it entails competitive advantage. What can other cities with intentions to promote eco-policies learn from Toyama City's case? As is Toyama City, most cities, if not all, have limited financial, human, and technological resources. Toyama City's case suggests that cities should focus on investing their resources into one or a few segments that are crucial in promoting their eco-policies, such as transportation and energy. In the case of Toyama City's eco-policy, that was public transportation, notably LRT, and to a lesser extent, sustainable energy, agriculture, business, and so forth. If one specific segment becomes a competitive advantage, unique with great value, it can attract additional resources for other segments such as business and agriculture, as illustrated by Toyama City.

Toyota City therefore should also focus on developing one or a few unique eco-items to promote its own eco-policy. A potential eco-item unique for Toyota City may be Ecoful Town, a showcase pavilion supported by the Toyota Motor Corporation and a driving force of promoting its eco-policy. Yet, it may not be as impactful as LRT, which is becoming a practical public transportation for Toyama citizens. Ecoful Town is also planned to be closed down after finishing its role as a showcase pavilion of Toyota City's eco-policy. Instead, the eco-family card/Toyota eco-points can be a unique sales point of Toyota City's eco-policy, we will be described in the 
following Chapter. The detailed description of Toyama's eco-policy goes beyond the scope of this study. However, future research will include it, possibly for comparative studies between the eco-policies of Toyama City and Toyota City. That way, Toyota City and other eco-cities will learn from Toyama City in promoting eco-policy. As Parsons ad Lepkowska-White (2018) note, monitoring "competitors" helps learn basic information about them and what creative approaches they use to generate supporters.

\section{Conclusion}

Overall, given internal and external factors examined in this study, Toyota City's eco-policy is not moving in a wrong direction. The Japanese government and the international community as well as the private sector are supportive of environmental initiatives, certainly advantageous for Toyota City to promote its eco-policy. However, there still remain issues of the promotion of the eco-policy locally and internationally. Locally, citizens' recognitions of some eco-themes are lacking, and few citizens act on eco-items comprising eco-policy. Internationally, the city's eco-policy has not yet been recognized by the international community. As a reference for Toyota City to promote eco-policy, this study mentioned Toyama City as an exemplary eco-city. Toyama City has been selected as a model city by various national and international environmental initiatives, whereas Toyota City has been selected as one national environmental initiatives. Toyota City therefore could learn how to promote eco-policy from the case of Toyama City, for example, focusing on one eco-item comprising the eco-policy (e.g., the eco-family card/Toyota eco-points).

\section{Acknowledgments}

I would like to thank Mr. Daiki Mizutani from Toyota City Hall for supporting me with research. I also would like to thank Ezra Anton Greene for editing this paper.

\section{References}

100 Resilient Cities. (2017). Resilient Toyama. Retrieved from https://www.100resilientcities.org/wp-content/ uploads/2017/07/Toyama_Resilience_Strategy__PDF.pdf

Aspara, J., \& Tikkanen, H. (2016). Why do public policy-makers ignore marketing and consumer research? A case study of policy-making for alcohol advertising. Consumption Markets \& Culture, 20(1), 1-23.

Blery, E. K., Katseli, E., \& Tsara, N. (2010). Marketing for a non-profit organization. International Review of Public and Nonprofit Marketing, 7, 57-68. https://doi.org/10.1007/s12208-010-0049-2

Boenigk, S., \& Möhlmann, M. (2016). A public sector marketing model to measure the social and environmental values of public strategies: An empirical study of green public service. Journal of Nonprofit \& Public Sector Marketing, 28(2), 85-104. https://doi.org/10.1080/10495142.2014.987036

Bovaird, T. (2003). Marketing in public sector organizations. In T. Bovaird, \& E. Löffler (Eds.), Public management and governance (pp. 81-94).

Burton, S. (1999). Marketing for public organizations. Public Management: An International Journal of Research, and Theory, 1(3), 373-385. https://doi.org/10.1080/14719039900000012

Butler, P., \& Collins, N. (1995). Marketing public sector services: Concepts and characteristics. Journal of Marketing Management, 11, 83-96. https://doi.org/10.1080/0267257X.1995.9964331

Butler, P., Collins, N., \& Fellenz, M. R. (2007). Theory-building in political marketing: Parallels in public management. Journal of Political Marketing, 6(2/3), 91-107. https://doi.org/10.1300/J199v06n02_06

Cabinet of Japan. (2012). Assessment of environmental model cities. Retrieved from https://www.kantei.go.jp/jp/singi/tiiki/kankyo/upload/130124\%20hyoukatyousa\%207/shiryo_4.pdf

Campbell, B. A., Coff, R., \& Kryscynski, D. (2012). Rethinking sustained competitive advantage from human capital. Academy of Management Review, 37(3), 315-318. https://doi.org/10.5465/amr.2010.0276

Chamorro, A., Rubio, S., \& Miranda, F. J. (2009). Characteristics of research on green marketing. Business Strategy and the Environment, 18(1), 223-239. https://doi.org/10.1002/bse.571

Collins, K., Tapp, A., \& Pressley, A. (2010). Social marketing and social influences: Using social ecology as a theoretical framework. Journal of Marketing Management, 26(13-14), 1181-1200. https://doi.org/10.1080/0267257X.2010.522529

Coman, A., \& Ronen, B. (2009). Focused SWOT: Diagnosing critical strengths and weaknesses. International Journal of Production Research, 47(20), 5677-5689. https://doi.org/10.1080/00207540802146130

Constantinides, E. (2006). The marketing mix revisited: Towards the $21^{\text {st }}$ century marketing. Journal of 
Marketing Management, 22, 407-438. https://doi.org/10.1362/026725706776861190

D’Souza, C., Marjoribanks, T., Young, S., Mort, G. S., Nanere, M., \& John, J. J. (2018). Environmental management systems: an alternative marketing strategy for sustainability. Journal of Strategic Marketing (in Press). https://doi.org/10.1080/0965254X.2018.1430054

Da Silva, C. E., \& Mazzon, J. A. (2016). Developing social marketing plan for health promotion. International Journal of Public Administration, 39(8), 577-586. https://doi.org/10.1080/01900692.2015.1023447

Denhardt, J. V., \& Denhardt, R. B. (2015). The new public service revisited. Public Administration Review, 75(5), 664-672. https://doi.org/10.1111/puar.12347

Ehmke, C. (2012). Strategies for competitive advantage. Retrieved from http://Ag.arizona.edu/arec/wemc/ nichemarkets/05compatitiveadvantage.pdf

French, J., \& Russell-Bennet, R. (2015). Hierarchical Model of Social Marketing. Journal of Social Marketing, 5(2), 139-159. https://doi.org/10.1108/JSOCM-06-2014-0042

Future City Initiative. Concept of "FutureCity" Initiative. Retrieved from https://www.env.go.jp/policy/hakusyo/ $\mathrm{zu} / \mathrm{h} 25 / \mathrm{pdf} / 1-2 . \mathrm{pdf}$

Gaddis Ross, D. (2014). Taking a chance: A formal model of how firms use risk in strategic interaction with other firms. Academy of Management Review, 39(2), 202-226. https://doi.org/10.5465/amr.2012.0107

Goldsmith, G. (2013). Rethinking the company's competitive advantage. Financial Executive, 29, 14-17.

Gregory-Smith, D., Wells, V. K., Manika, D., \& Graham, S. (2015). An environmental social marketing intervention among employees: assessing attitude and behavior change. Journal of Marketing Management, 31(3-4), 336-377. https://doi.org/10.1080/0267257X.2014.971045

Halík, J. (2012). The application of PEST analysis based on EBRD and IBRD methodology. Central European Business Review, 1(3), 14-21. https://doi.org/10.18267/j.cebr.26

Hargadon, A., \& Sutton, R. I. (2000). Building an innovation factory. Harvard Business Review, 78(3), 157-166.

Helmig, B., \& Thaler, J. (2010). On the effectiveness of social marketing - What do we really know? Journal of Nonprofit \& Public Sector Marketing, 22, 264-287. https://doi.org/10.1080/10495140903566698

Hill, T., \& Westbrook, R. (1997). SWOT analysis: It's time for a product recall. Long Range Planning, 30(1), 46-52. https://doi.org/10.1016/S0024-6301(96)00095-7

Hsieh, Y. H., \& Chen, H. M. (2011). Strategic fit among business competitive strategy, human resource strategy, and reward system. Academy of Strategic Management Journal, 10(2), 11-32.

Huselid, M. A. (1995). The impact of human resource management practices on turnover, productivity, and corporate financial performance. The Academy of Management Journal, 38(3), 635-672.

Ito, H. (2017). Underlying gaps between environmental knowledge and behavior in the city of Toyota: Phase III. Asian Social Science, 13(10), 23-30. https://doi.org/10.5539/ass.v13n10p23

Ito, H., \& Kawazoe, N. (2016). A review of Toyota City's eco-policy: Changes in citizens' awareness between 2012 and 2015. Urban research and Practice, 11(1), 1-19.

Ito, H., \& Kawazoe, N. (2017). The associations between socio-demographic factors and environmental knowledge in the city of Toyota, Japan. Applied Environmental Education \& Communication, 17(2), 1-14.

Jahromi, Z. F., Rajabzadeh, A., \& Manashty, A. R. (2011). A multi-purpose scenario-based simulator for smart house environments. International Journal of Computer Science and Information Security, 9(1), 13-18.

Jain, S. K., \& Kaur, G. (2004). Green marketing: An Indian perspective. Management Decision, 31, 168-209.

Johnson, G., Whittington, R., \& Scholes, K. (2011). Exploring strategy. Upper Saddle River, New Jersey: Prentice Hall.

Joldersma, C., \& Winter, V. (2002). Strategic management in hybrid organizations. Public Management Review, 4(1), 83-99. https://doi.org/10.1080/14616670110101708

Kanno, H. (2014). Keiei no shippaigaku (Failure studies of management). Tokyo: Nihon Keizai Syuppansya.

Kaplan, A. M., \& Haenlein, M. (2009). The increasing importance of public marketing: Explanations, applications and limits of marketing within public administration. European Management Journal, 27, 197-212. https://doi.org/10.1016/j.emj.2008.10.003 
Kim, W. C., \& Mauborgne, R. (1997). Value innovation: the Strategic logic of high growth. Harvard Business Review, 75(1), 102-112.

Kirchgeorg, M., \& Winn, M. I. (2006). Sustainability Marketing for the Poorest of the Poor. Business Strategy and the Environment, 15, 171-184. https://doi.org/10.1002/bse.523

Kotler, P., \& Keller, K. (2011). Marketing management (14th ed.). New Jersey: Prentice Hall.

Kotler, P., \& Zaltman, G. (1971). Social marketing: An approach to planned social change. Journal of Marketing, 35(3), 3-12. https://doi.org/10.1177/002224297103500302

Kyoto City. (2015). Kyoto Environmental Model City Action Plans. Retrieved from http://www.city.kyoto.lg.jp/kankyo/cmsfiles/contents/0000056/56642/kyoto-actionplan-honpen.pdf

Laing, A. (2003). Marketing in the public sector: Towards a typology of public services. Marketing Theory, 3(4), 427-445. https://doi.org/10.1177/1470593103042005

Laing, A., \& McKee, L. (2001). Willing volunteers or unwilling conscripts? Professionals and marketing in service organizations. Journal of Marketing Management, 17(5-6), 559-576. https://doi.org/10.1362/026725701323366935

Lankard, A., \& McLaughlin, W. J. (2003). Marketing an environmental issue: A case study of the wilderness society's core messages to promote national forest conservation from 1964 to 2000 . Society \& Natural Resources, 16(5), 415-434. https://doi.org/10.1080/08941920309178

Lebeau, K., Lebeau, P., Macharis, C., \& Meirlo, J. V. (2013). EVS 27 International Battery, Hybrid and Fuel Cell Electric Vehicle Symposium. Barcelona, Spain.

Madill, J., \& Abele, F. (2007). From public education to social marketing: The evolution of the Canadian heritage anti-racism social marketing program. Journal of Nonprofit \& Public Sector Marketing, 17(1-2), 27-53. https://doi.org/10.1300/J054v17n01_02

Marlin, D., Ketchen, D. J., \& Lamont, B. (2007). Equifinality and the strategic groups: Performance relationship. Journal of Managerial Issues, 19(2), 208-232.

Masih-Tehrani, M., Ha'iri-Yazdi, M.-R., Esfahanian, V., \& Safaei, A. (2013). Optimum sizing and optimum energy management of a hybrid energy storage system for lithium battery life improvement. Journal of Power Sources, 244, 2-10. https://doi.org/10.1016/j.jpowsour.2013.04.154

McGee, J., \& Thomas, H. (1986). Strategic groups: Theory, research and taxonomy. Strategic Management Journal, 7(2), 141-160. https://doi.org/10.1002/smj.4250070204

McMahon, L. (2002). The impact of social marketing on social engineering in economic restructuring. Journal of Nonprofit \& Public Sector Marketing, 9(4), 75-84. https://doi.org/10.1300/J054v09n04_07

Ministry of the Environment. (2012). White papers for the environment. Retrieved from https://www.env.go.jp/policy/hakusyo/zu/h25/pdf/1-2.pdf

Molander, S., Fellesson, M., \& Friman, M. (2018). Market orientation in public service: A comparison between buyers and providers. Journal of Nonprofit \& Public Sector Marketing, 30(1), 74-94. https://doi.org/10.1080/10495142.2017.1326342

Nagahama, Y. (2014). Marketing for nonprofit organizations. Tokyo: Gakugei-syuppan.

Nagasaka, T. (2007). The current situation and development of the NPO sector in Japan. International Trade and Investment, 67, 91-101.

OECD. (2013). Green growth in Kitakyushu, Japan. Paris: OECD. https://doi.org/10.1787/9789264195134-en

Osborne, D., \& Gaebler, T. (1992). Reinventing government: How the entrepreneurial spirit is transforming the public sector. Reading, MA: Addison-Wesley.

Pandey, S., Kim, M., \& Pandey, S. K. (2017). Do mission statements matter for nonprofit performance? Insights from a study of US performing arts organizations. Nonprofit Management \& Leadership, 27(3), 389-410. https://doi.org/10.1002/nml.21257

Parker, R., Kaufman-Scarborough, \& Parker, J. C. (2007). Libraries in transition to a marketing orientation: Are librarians' attitudes a barrier? International Journal of Nonprofit and Voluntary Sector Marketing, 12(4), 320-337. https://doi.org/10.1002/nvsm.295

Parsons, A. L., \& Lepkowska-White, E. (2018). Social media marketing management: A conceptual framework. 
Journal of Internet Commerce, 17(2), 81-95. https://doi.org/10.1080/15332861.2018.1433910

Peattie, K. (2001). Toward sustainability: The third age of green marketing. The Marketing Review, 2(2), 129-146. https://doi.org/10.1362/1469347012569869

Peattie, S., \& Peattie, K. (2003). Ready to fly solo? Reducing social marketing's dependence on commercial marketing theory. Marketing Theory, 3(3), 365-385. https://doi.org/10.1177/147059310333006

Pegels, C. C., \& Sekar, C. (1989). Determining strategic groups using multidimensional scaling. Interfaces, 19(3), 47-57. https://doi.org/10.1287/inte.19.3.47

Pekkanen, R. (2006). Japan's Dual Civil Society: Members Without Advocates. Palo Alto, CA: Stanford University Press.

Poister, T. H. (2003). Measuring performance in public and nonprofit organizations. San Francisco, CA: Jossey-Bass.

Polonsky, M. J. (1994). A stakeholder theory approach to designing environmental marketing strategy. Unpublished Working Paper.

Porter, M. E. (1979). The structure within industries and companies' performance. Review of Economics and Statistics, 61, 214-227. https://doi.org/10.2307/1924589

Porter, M. E. (1985). Competitive advantage. New York: Free Press.

Rettie, R., Burchell, K., \& Riley, D. (2012). Normalising green behaviors: A new approach to sustainability marketing. J. of Marketing Management, 28(3-4), 420-444. https://doi.org/10.1080/0267257X.2012.658840

Rundle-Thiele, S. (2015). Looking back and moving forwards: An agenda for social marketing research. Recherche et Applications en Marketing, 30(3), 128-133. https://doi.org/10.1177/2051570715599338

Sargeant, A. (2009). Marketing management for nonprofit organizations. Oxford: Oxford University Press.

Scrivens, E. (1991). Is there a role for marketing in the public sector. Public Money \& Management, 11(2), 17-23. https://doi.org/10.1080/09540969109387650

Smith, K. T., \& Brower, T. R. (2012). Longitudinal study of green marketing strategies that influence Millennials. Journal of Strategic Marketing, 20(6), 535-551. https://doi.org/10.1080/0965254X.2012.711345

Takahashi, B. (2009). Social marketing for the environment: An assessment of theory and practice. Applied Environmental Education \& Communication, 8, 135-145. https://doi.org/10.1080/15330150903135889

Taylor-Gooby, P., \& Wallace, A. (2009). Public values and public trust: Responses to welfare state reform. Journal of Social Policy, 38(3), 401-419. https://doi.org/10.1017/S0047279409003055

Thomas, H., \& Pruett, M. (1995). Strategic groups and the analysis of market structure and industry dynamics. British Journal of Management, 6, 257-270. https://doi.org/10.1111/j.1467-8551.1995.tb00099.x

Toyama City. (2015). Sustainable energy for all. Retrieved from http://www.city.toyama.toyama.jp/kankyobu/ kankyoseisakuka/ondankataisakukikaku/kankyomiraitoshi-_2_2_2.html

Toyota City. (2009). Summary of Action Plans towards an Environmental Model City. Retrieved from http://www.city.toyota.aichi.jp/division/an00/an06/1252190/02gaiyou.pdf

Toyota City. (2012). The Toyota greening system. Retrieved from http://www.city.toyota.aichi.jp/shisei/ machizukuri/keikan/1005270.html

Toyota City. (2014). Hybrid City Toyota: The second action plan of Toyota as an environmental model city. Retrieved from http://www.city.toyota.aichi.jp/_res/projects/default_project/_page_/001/008/301/02plan.pdf

Toyota City. (2017). Aiming at normalizing eco-life in the future. Retrieved from http://toyota-eco.jp

Toyota City. (2018). "Kankyou Mirai Toshi Kousou" (Planning for Environmental Future City). Retrieved from http:www.future-city.jp/torikumi/toyota

United Nations. (2015). Transforming our world: The 2030 agenda for sustainable development. New York: United Nations.

Walker, R. M., Brewer, G. A., Boyne, G. A., \& Avellaneda, C. N. (2011). Market orientation and public service performance: New public management gone mad? Public Administration Review, 71(5), 707-717. https://doi.org/10.1111/j.1540-6210.2011.02410.x

Walsh, K. (1991). Citizens and consumers: Marketing and public sector management. Public Money \& 
Management, 11(2), 9-17. https://doi.org/10.1080/09540969109387649

Wood, M. (2016). Social marketing for social change. Social Marketing Quarterly, 22(2), 107-118. https://doi.org/10.1177/1524500416633429

Wright, B. E., Moynihan, D. P., \& Pandey, S. K. (2012). Pulling the levers: Transformational leadership, public service motivation, and mission valence. Public Administration Review, 72(2), 206-215 https://doi.org/10.1111/j.1540-6210.2011.02496.x

Wymer, W., \& Polonsky, M. J. (2015). The limitations and potentialities of green marketing. Journal of Nonprofit \& Public Sector Marketing, 27, 239-262. https://doi.org/10.1080/10495142.2015.1053341

Yokohama City. (2015). Kankyou moderu toshi akusyon puran (Environmental Model City Action Plans). Retrieved from http://www.city.yokohama.lg.jp/ondan/plan/jikkou-kuiki/pdf/actionplan.pdf

\section{Copyrights}

Copyright for this article is retained by the author(s), with first publication rights granted to the journal.

This is an open-access article distributed under the terms and conditions of the Creative Commons Attribution license (http://creativecommons.org/licenses/by/4.0/). 